\title{
PENINGKATAN PRESTASI BELAJAR EKONOMI SISWA KELAS X IPA 1 LINTAS MINAT SMA NEGERI 1 GALUR MENGGUNAKAN MIND MAPPING
}

\author{
Oleh: Elisabeth Warniningsih \\ SMA Negeri 1 Galur Kulon Progo
}

\begin{abstract}
This study aims to find a way to increase the student achievement in studying economy by using mind mapping method in class X IPA 1 crossed interest lesson of SMAN 1 Galur. This study was a classroom action research with qualitative descriptive approach. This study conducted in two cycle whith three meetings in each cycle. There were 22 students participated as subject in this study. Each meeting applied the following steps: planning, action, and reflection. The data collecting instruments in this study were questionnaire, observation sheets, field note, attitude scale, and achievement test (daily test). The result of this study indicates that by using mind mapping, the learning process became more effective, the student activity during the learning process also more effective, enjoyable, and joyful. The method has positive effect of increasing the student achievement in economic that can be known from: (a) the increase of student activity and students motivation in cycle I and II; (b) the increase of students achievement in cognitive aspect (student learning completeness standard from $77.53 \%$ in cycle I and $82.63 \%$ in cycle II), and in affective aspect from the level of enough become excellent in the end of the study. Result of the study also supported by the assessment in learning process which was held by the collaborator, from the classification of $50 \%$ good to $50 \%$ excellent.
\end{abstract}

Keywords: mind mapping method, economy.

\section{PENDAHULUAN}

Pendidikan memegang peranan penting dalam kehidupan seseorang atau suatu bangsa. Kemajuan pembangunan suatu bangsa dapat dicapai dan pendidikan yang terarah dan berkesinambungan. Melalui pendidikan diciptakan manusia yang berakhlak mulia, cerdas, unggul, berbudaya dan berkepribadian. Untuk mewujudkan tujuan pendidikan yang benar pemerintah menetapkan Undang undang nomor 20 Tahun 2003 tentang Sistem Pendidikan Nasional yang penjabarannya pada pembelajaran di sekolah-sekolah.

Pada era globalisasi ini teknologi semakin maju, manusia semakin mudah mendapatkan informasi, menjangkau lingkup dunia dengan tidak bersusah payah, tetapi kemajuan teknologi juga ada dampak negatifnya, salah satunya para pelajar (siswa) motivasi belajarnya menjadi rendah, pasif dan tidak kreatif sehingga hasil belajar pada umunya rendah khususnya mata pelajaran ekonomi. Selain motivasi belajar siswa rendah, selama ini emage siswa bahwa ekonomi merupakan mata pelajaran yang sulit, abstrak, tidak menarik dan tidak menyenangkan. Image ini akan terus berlanjut manakala tidak segera diatasi baik model pembelajaran, metode atau strateginya agar tercipta pembelajaran yang menarik, menyenangkan dan bermakna. Upaya untuk mewujudkan proses pembelajaran

menjadi menarik, menyenangkan, mudah diterima dan mudah difahami, maka strategi pembelajaran ekonomi harus mengalami inovasi, sehingga dampak yang ditimbulkan adalah prestasi belajar ekonomi meningkat dengan kata lain tercapai ketuntasan belajarnya.

Fenomena di atas inemotivasi penenliti untuk mengadakan penelitian tindakan kelas yang berkaitan dengan upaya peningkatan prestasi belajar ekonomi siswa menggunakan model pembelajaran mind mapping, serta dukungan teman sejawat, pengawas ekonomi, dengan harapan meningkatnya prestasi belajar ekonomi siswa. 
Selain permasalahan di atas, muncul beberapa permasalahan yang berkaitan dengan prestasi belajar ekonomi siswa yang meliputi: Rencana pelaksanaan pembelajaran (RPP) yang dibuat guru belum maksimal, metode pembelajaran yang kurang menekankan keaktifan siswa, media pembelajaran ekonomi yang kurang menarik, strategi pembelajaran yang kurang sesuai dengan konsep yang dipelajari, dan motivasi belajar siswa rendah.

Adapun permasalahan penelitian ini dibatasi sebagai berikut: upaya peningkatan prestasi belajar ekonomi siswa dilaksanakan menggunakan mind mapping, hasil belajar ekonomi siswa aspek afektif yang merupakan indikator keaktifan belajar siswa, hasil belajar ekonomi siswa aspek kognitif yang merupakan indikator prestasi belajar siswa, konsep ekonomi pada penelitian ini adalah harga keseimbangan pasar yang merupakan materi hafalan juga ada rumus-rumus permintaan dan penawaran yang harus dipelajari dan susah dipahami atau diingat oleh siswa. Tujuan penelitian ini adalah untuk meningkatkan prestas belajar ekonomi melalui model pembelajaran mind mapping pada siswa kelas X IPA 1 lintas minat SMA N 1 Galur Kulon Progo.

\section{METODE PENELITIAN}

Penelitian tentang upaya peningkatan prestasi belajar ekonomi siswa menggunakan mind mapping ini dilaksanakan di SMA N 1 Galur Kulon Progo. Alasan dipilihnya tempat tersebut adalah peneliti ingin meningkatkan kinerjanya sebagai guru, serta ingin meningkatkan keaktifan siswa yang selama ini masih sulit terwujud serta ingin meningkatkan prestasi belajar siswa. Penelitian dilaksanakan pada akhir bulan September 2018 sampai dengan bulan Nopember 2018, menggunakan Penelitian Tindakan Kelas (PTK).

Refleksi awal (reconnaissance) dan perencanaan, dilaksanakan pada akhir September 2018. Tindakan, observasi dan refleksi I dilaksanakan pada awal bulan, Oktober sampai dengan akhir Oktober 2018. Rencana terevisi I, tindakan dan observasi II, refleksi II dilaksanakan pada awal Nopember 2015. Triangulasi dan membuat laporan penelitian dilaksanakan pada pertengahan bulan Nopember sampai dengan awal Desember 2018.

Penelitian ini dilakukan secara kolaboratif dan siklik dalam dua siklus, yakni perenungan untuk menentukan masalah, perencanaan (planning), tindakan (acting), dan observasi (observing), serta refleksi (reflecting).

Penenlitian ini merupakan Penelitian Tindakan Kelas (PTK) seperti yang diketengahkan oaleh Burns (1999:29-30) mengutip pendapat beberapa para ahli yang terkenal yang dikemukakan oleh Carr dan Kemmis bahwa: penelitian tindakan merupakan suatu bentuk penelitian yang bersifat reflektif yang dilakukan oleh guru dalam masyarakat sosial dan bertujuan untuk memperbaiki pekerjaanya, memahami pekerjaan, dan situasi pekerjaan itu dilakukan.

Kemmis dan Mc. Taggart (Burns, 1999: 13) menyatakan pentingnya kolaboratif dalam penelitian tindakan. Permasalahan yang dipecahkan harus didiskusikan dengan seluruh anggota yang terlibat. Kolaborasi di sini berarti seluruh anggota yang terlibat aktif memberikan kontribusi terhadap bentuk tindakan yang dilakukan untuk membuat perubahan atas permasalahan yang terjadi.

Dengan dasar teori tersebut maka penelitian ini dilaksanakan dengan bersiklus yang meliputi refleksi awal (reconnaissance) dan perencanaan, tindakan, observasi dan refleksi I, rencana terevisi I, tindakan dan observasi II, refleksi II, dilanjutkan rencana terevisi II, tindakan III, refleksi III, serta triangulasi dan membuat laporan penelitian.

Penelitian ini merupakan penelitian tindakan kelas (classroom action research), yang berfokus pada upaya untuk mengubah kondisi nil sekarang ke arah kondisi yang 
diharapkan (improvement oriented). Subjek dalam penelitian ini adalah siswa. Guru peneliti adalah guru ekonomi kelas X IPA SMA N 1 Galur, sedangkan siswa yang terlibat dalam penelitian tersebut adalah siswa - siswa kelas X IPA yang pada semester II akan menghadapi Ujian Akhir Sekolah, sehingga diupayakan perbaikan proses pembelajaran agar dapat tercapai ketuntasan belajar ekonomi serta dampak selanjutnya nilai Ujian Kenaikan Kelas meningkat.

Pada penelitian ini digunakan model pembelajaran Mind Mapping dengan tujuan untuk membantu siswa memaksimalkan potensi pikiran dengan menggunakan otak kanan dan otak kiri secara simultan agar dapat memahami suatu konsep atau materi tertentu.

Beberapa metode yang berpusat pada siswa (students centered) antara lain (Mulyati, 2003: 118): a) metode ceramah bermakna, b)metode eksperimen,c) metode demonstrasi, d) metode pemecahan masalah, e) metode diskusi.

Metode yang digunakan pada penelitian ini adalah metode diskusi, yaitu metode yang mengharapkan adanya interaksi antara siswa dengan guru, siswa dengan siswa, dimana

Interaksi tersebut juga bersifat mengembangkan materi, keterampilan, sikap atau keterampilan proses. Ada beberapa keuntungan penggunaan metode diskusi dalam pembelajaran antara lain: 1) dapat meningkatkan rasa toleransi siswa, 2) memperluas wawasan dengan saling tukar ide, 3) meningkatkan keterampilan proses secara aktif, 4) meningkatkan kemampuan siswa dalam memecahkan masalah, 5) meningkatkan kemampuan siswa dalam kepemimpinan, organisasi dan inisiatif.

Untuk menghindari kesalahan pengertian dalam memahami istilah pada penelitian ini, diberikan definisi operasional variabel sebagai berikut: Prestasi Belajar adalah basil yang dicapai oleh sesorang setelah is melakukan perubahan belajar baik di sekolah maupun di luar sekolah.
Mind Mapping adalah suatu metode untuk memaksimalkan potensi pikiran manusia dengan menggunakan otak kanan dan otak kiri secara simultan. Pakar lain mendefinisikan mid mapping merupaakam teknik visualisasi verbal ke dalam gambar yang dapat membantu merekam, memperkuat, dan mengingat kembali informasi yang telah dipelajari (Jensen dan Makowitz, 2002). Model pembelajaran mind mapping memiliki banyak keunggulan. Menurut Buzan, (2008) mind mapping dapat membantu banyak hal seperti: 1) Merencanakan, 2) Berkomunikasi, 3) Menjadi lebih kreatif, 4) Menyelesaikan masalah, 5) Memusatkan perhatian, 6) Menyusun dan menjelaskan pikiran-pikiran, 7) Mengingat dengan baik, 8) Belajar lebih cepat dan efisien, 9) Melatih " gambar keseluruhan". Relevan dengan dua pengertian itu, dapat disimpulkan bahwa mind mapping adalah metode pembelajaran yang mampu menggambarkan sebuah tema, ide, atau gagasan utama dalam materi pelajaran dengan memadukan teknik visual dan verbal.

Pendapat pakar lain memberikan gambaran dalam menggunakan mind mapping antara lain: 1) Pusat peta pikiran atau central topic, merupakan ide atau gagasan utama; 2) Cabang utama atau basic ordering ideas (BOI), cabang tingkat pertama yang langsung inemancar dari pusat peta pikiran; 3) Cabang, merupakan pancaran dari cabang utama, dapat dituliskan ke segala arah; 4) Kata, menggunakan kata kunci saja; 5) Gambar, dapat menggunakan gambar-gambar yang disukainya; 6) dan warna, gunakan warna warni yang menarik dalam peta pikiran (Alamsyah, 2009). Mind Mapping merupakan salah satu model pembelajaran untuk membantu siswa memahami suatu konsep atau materi tertentu.

Instrumen yang digunakan untuk penelitian dan teknik pengumpulan data adalah instrumen proses dan hasil. Instrumen proses adalah instrumen untuk mengetahui efektif tidaknya proses pembelajaran ekonomi 
sedangkan instumen hasil adalah instrumen untuk mengetahui prestasi belajar siswa. Instrumen tersebut meliputi: 1) Instrumen untuk mengetahui efektif tidaknya proses pembelajaran dengan menilai aspek perencanaan pembelajaran, dan aspek afektif pada saat proses pembelajaran dengan mind mapping berlangsung (dilakukan oleh kolaborator menggunakan lembar observasi).

2) Instrumen untuk mengetahui prestasi belajar ekonomi siswa dengan butir soal atau ulangan harian (dilakukan oleh guru peneliti menggunakan lembar soal/ulangan).

Teknik pengumpulan data pada penelitian ini adalah: 1) Observasi Kelas, Observasi kelas dipergunakan untuk memperoleh data tentang perilaku siswa dan perilaku guru (peneliti) selama berlangsungnya proses pembelajaran ekonomi. Observasi ini untuk mengetahui perubahan yang terjadi pada proses pembelajaran ekonomi baik sebelum maupun sesudah dilakukan tindakan penelitian. Observasi ini dilakukan oleh kolaborator. Observasi kelas juga didukung dengan fotografi. Hasil observasi kelas berupa catatan lapangan dan foto, serta data berupa angkaangka Skala Perbedaan Semantik (SPS). 2) Wawancara, Wawancara dilakukan untuk mengetahui data tentang perilaku siswa dan perilaku guru peneliti selama dan sesudah proses pembelajaran ekonomi. Wawancara yang dilakukan berupa wawancara terencana tetapi tak terstruktur. Pada awal wawancara diberikan satu dua pertanyaan sebagai pembuka, dilanjutkan dengan memberikan kesempatan kepada responden untuk menjawab pertanyaan secara terbuka. Pewawancara mengajukan pertanyaan untuk menggali dan memperjelas adanya perubahan proses pembelajaran sebelum dan sesudah dilakukan tindakan. Wawancara dilakukan oleh guru (peneliti) kepada siswa-siswa kelas X IPA, dan kolaborator. 3) Tes (ulangan Harian). Tes (ulangan harian) untuk mengetahui prestasi belajar ekonomi siswa sekaligus tingkat ketuntasan belajar ekonomi siswa. Ulangan harian dilaksanakan setiap akhir siklus, dan hasil ulangan dianalisis untuk mengetahui daya serap siswa sekaligus ketuntasan belajar siswa baik secara individual maupun klasikal. Kriteria ketuntasan mata pelajaran ekonomi di SMA N 1 Galur adalah 75. Bagi para siswa yang sudah mencapai nilai 75 ke atas maka sudah dikatakan tuntas, dan siswa yang mendapatkan nilai ulangan kurang dari 75, maka dilaksanakan perbaikan (remidial). Siswa-siswa yang sudah tuntas diberikan pengayaan.

Teknik Analisis Data adalah data penelitian yang berupa data kualitatif dianalisis dan catatan lapangan dan transkip hasil wawancara. Data penelitian yang berupa data kuantitatif dianalisis secara diskriptif analitik yang bersifat eksplanatorik, yaitu dengan penyajian tabel-tabel, dan persentase. Penyajian data dalam bentuk persentase selanjutnya didskripsikan dan diambil kesimpulan tentang masing-masing komponen. Untuk mendukung keberhasilan proses pembelajaran sekaligus ketuntasan belajar atau prestasi belajar siswa diadakan tes (ulangan harian). Hasil tes dianalisis untuk mengetahui daya serap dan ketuntasan belajar siswa. Untuk menghindari subjektivitas, peneliti menggunakan triangulasi yaitu teknik pemeriksaan data dengan memanfaatkan sesuatu yang lain di luar data.

Adapun langkah-langkah analisisnya sebagai berikut:

1. Analisis penilaian proses pembelajaran dengan jumlah butir instrumen penilaian proses pembelajaran 20 pertanyaan dengan pilihan jawaban model skala perbedaan semantik. Skor yang diberikan adalah 1 sampai 5, dengan kategori sebagai berikut: skala 5 = sangat baik, skala $4=$ baik, skala $3=$ cukup, skala $2=$ kurang, dan skala $1=$ sangat kurang. Hal ini berarti skor ideal tertinggi 100 dan skor ideal terendah 20, dan ditentukan prosentase pada setiap kategori. 
2. Analisis penilaian aspek afektif siswa dengan jumlah butir instrumen penilaian aspek afektif siswa 6 pertanyaan dengan pilihan jawaban model skala perpedaan semantik. Skor yang diberikan adalah 1 sampai 5, dengan kategori sebagai berikut: skala 5 = sangat baik, skala $4=$ baik, skala $3=$ cukup, skala $2=$ kurang, dan skala $1=$ sangat kurang. Hal ini berarti skor ideal tertinggi 30 dan skor ideal terendah 6 .

Penelitian ini dilaksanakan melalui tahapan sebagai berikut:

\section{Refleksi Awal}

Pada tahap ini peneliti bersama kolaborator mengadakan observasi kelas awal untuk melihat keadaan proses pembelajaran sebelum diberi tindakan dan menyusun skenario pembelajaran yang akan diimplementasikan di kelas. Skenario tindakan pembelajaran meliputi tujuan, jenis kegiatan guru dan siswa, draf pembelajaran, draf instrumen perekam data, maupun teknis pelaksanaannya.

2. Perencanaan

Setelah dilakukan observasi awal, selanjutnya peneliti merencanakan skenario pembelajaran dan menyiapkan fasilitas dan sarana pendukung untuk melaksanakan skenario tindakan. Setelah seluruh fasilitas yang dibutuhkan siap, rencana tindakan disimulasikan untuk mereduksi kesalahan sekecil mungkin dan memberikan gambaran konkrit tindakan yang akan dilakukan terutama dalam KD permintaan dan penawaran sehingga terjadi harga keseimbangan pasar. Kegiatan yang akan dilakukan pada tahap ini adalah: 1) Membuat skenario pembelajaran. 2) Menyiapkan media. 3) Menyiapkan instumen observasi serta wawancara. 4) Menyiapkan kegiatan refleksi guna menemukan pemecahan masalah pada siklus berikutnya.

3. Pelaksanaan

Pada tahap ini skenario pembelajaran diimplementasikan di kelas. Proses pembelajaran dengan menggunakan model pembelajaran mind mapping dilakukan di kelas X IPA. Pada saat tindakan berlangsung, kolaborator melakukan observasi dengan menggunakan insturumen yang telah disediakan. Kolaborator mencatat data yang ada, dan juga diminta untuk memberikan interprestasinya atas berbagai masalah yang dijumpai. Untuk memudahkan kolaborator dalam memberikan penilaian, peneliti telah menyediakan instrumen dalam bentuk Skala Perbedaan Semantik (SPS), dan catatan lapangan secara terbuka. Peneliti selain melakukan tindakan juga mencatat berbagai reaksi siswa pada saat tindakan berlangsung.

4. Refleksi

Hasil observasi kelas, rekaman data, diskusi balikan dan berbagai temuan yang lain, dibawa ke forum refleksi untuk dianalisis oleh semua peserta penelitian secara bersamasama. Hasil analisis tersebut kemudian digunakan untuk merencanakan kagiatan pada siklus berikutnya. Tindakan yang berhasil dilanjutkan pada proses pembelajaran berikutnya, sedangkan tindakan yang tidak berhasil diubah dan diperbaiki.

\section{Kriteria Keberhasilan}

Pembelajaran yang efektif dapat dilihat apabila siswa semakin bergairah, aktif, konsentrasi, saling berdiskusi dan tidak saling cekcok dan ingin pelajaran terus berlangsung. Menurut Bloom (Block, 1971: 3), prinsip belajar tuntas (mastery learning) adalah suatu sistem belajar yang mengharapkan sebagian siswa dapat menguasai tujuan instruksional umum dan unit pelajaran secara tuntas. Standar penguasaan tuntas itu yaitu $75 \%$ $90 \%$ dari semua siswa menguasai tujuan instruksional. Penelitian ini dikatakan berhasil jika 75\% siswa telah mencapai Kriteria Ketuntasan Minimal (KKM).

\section{HASIL DAN PEMBAHASAN Siklus I}

Proses pembelajaran menggunakan mind mapping tatap muka I, siklus I ini, belum begitu tampak adanya perubahan yang 
berarti pada komponen-komponen yang diamati seperti sikap siswa dalam kelompok, partisipasi, perilaku, dan interaksi antar siswa. Mind mapping belum berfungsi, beberapa siswa masih bingung memahami materi yang ada pada mind mapping, masih membuka buka buku paket, pembelajaran masih didominasi oleh guru. Untuk menentukan kategori penilaian proses pembelajaran dan penilaian aspek afektif yaitu ditentukan persentase pada setiap kategori penilaian. Dan basil analisis data penilaian proses pembelajaran dan analisis data penilaian aspek afektif siswa dapat diketahui masing-masing kategorinya. Data yang diperoleh dari kedua kolaborator pada proses pembelajaran tatap muka I, siklus I, sebagai berikut:

\section{Penilaian Proses Pembelajaran}

Berdasarkan penilaian kolaborator terhadap proses pembelajaran dengan mind mapping (menggunakan instrumen I), kolaborator memberikan jumlah skor 66, aspek pengamatan atau $66: 20=3,3$, maka penilaian proses pembelajaran kategorinya cukup. Distribusi frekuensi skor dapat dilihat pada tabel 1 berikut.

Tabel 1. Rekapitulasi Penilaian Proses Pembelajaran dengan model Mind Mapping Siklus I Tatap Muka 1

\begin{tabular}{|c|c|c|c|}
\hline No. & Kategori & Frekuensi & $\%$ \\
\hline 1 & Sangat Baik & 0 & 0 \\
\hline 2 & Baik & 5 & 25 \\
\hline 3 & Cukup & 15 & 75 \\
\hline 4 & Kurang & 0 & 0 \\
\hline 5 & Sangat Kurang & 0 & 0 \\
\hline & Jumlah & 20 & 100 \\
\hline
\end{tabular}
pembelajaran terdapat pada kategori cukup sebesar $75 \%$ dan $25 \%$ baik.

\section{Penilaian Aspek Afektif Siswa}

Berdasarkan penilaian kolaborator terhadap aspek afektif siswa (instrumen II), diperoleh rata-rata jumlah skor 18 (lihat lampiran). Untuk menentukan kategori penilaian aspek afektif siswa jumlah skor rata-rata dibagi jumlah aspek pengamatan $(18: 6=3)$, maka kategorinya cukup.

Refleksi dari kolaborator pada tatap muka I, siklus I dapat dirangkum dan difokuskan pada: mind mapping hendaknya dimaksialkan, diciptakan interaksi antar siswa, pemberian motivasi agar siswa aktif perlu ditingkatkan, pemberian pujian (reward) perlu ditingkatkan, pengelolaan kelas perlu ditingkatkan, menejemen waktu perlu diperhatikan agar pretes dan posttes dapat dilaksanakan dengan baik.

Tatap muka 2, siklus I, keaktifan siswa sudah mengalami peningkatan dibanding tatap muka sebelumnya, walaupun masih ada beberapa siswa yang masih cenderung diam, mind mapping sudah mulai berfungsi, siswa sesekali saja membuka buku paket apabila di dalam mind mapping belum tertulis. Dalam presentasi sudah ada beberapa siswa yang mau menanggapi hasil diskusi kelompok lain, manajemen waktu masih kurang sehingga belum semua kelompok mempresentasikan basil diskusinya, namun demikian sudah ada peningkatan dibanding sebelumnya

Refleksi tatap muka 2, siklus I, oleh kolaborator bersama peneliti sebagai berikut: proses pembelajaran dengan min mapping sudah menunjukkan tanda-tanda perbaikan, hal ini dapat dilihat dari beberapa indikator: banyak siswa yang aktif. Pendekatan guru dalam memantau dan mengamati siswa dengan teknik chennel sudah cukup baik, situasi pembelajaran nyaman. Manajemen waktu perlu ditingkatkan, pemberian motivasi juga perlu ditingkatkan, dan guru hendaknya menayangkan kesimpulan. Peningkatan proses pembelajaran juga dapat dilihat dari hasil analisis penilaian proses pembelajaran, keaktifan siswa juga dapat dilihat dari hasil analisis lembar observasi penilaian aspek afektif siswa sebagai berikut: 1. Penilaian Proses Pembelajaran

Berdasarkan penilaian kolaborator terhadap proses pembelajaran mind mapping (menggunakan instrumen I), kolaborator 
memberikan jumlah skor 70. Untuk menentukan kategori penilaian adalah jumlah butir aspek pengamatan atau $70: 20=3,5$, maka penilaian proses pembelajaran kategorinya cukup. Distribusi frekuensi skor terdapat pada tabel 2 berikut.

Tabel 2. Rekapitulasi Penilaian Proses Pembelajaran menggunakan Mind Mapping

Siklus I, Tatap Muka 2

\begin{tabular}{rlcc}
\hline No. & Kategori & Frekuensi & $\%$ \\
\hline 1 & Sangat Baik & 0 & 0 \\
\hline 2 & Baik & 10 & 50 \\
\hline 3 & Cukup & 10 & 50 \\
\hline 4 & Kurang & 0 & 0 \\
\hline 5 & Sangat Kurang & 0 & 0 \\
\hline & Jumlah & 20 & 100 \\
\hline
\end{tabular}

Berdasarkan tabel 2, basil penilaian

oleh kolaborator terhadap proses pembelajaran terdapat pada kategori cukup sebesar $50 \%$ dan 50 baik.

2. Penilaian Aspek Afektif Siswa

Berdasarkan penilaian kolaborator terhadap aspek afektif siswa (instrumen $\mathrm{H}$ ), diperoleh jumlah skor rata-rata 20,8 (lihat lampiran). Untuk menentukan kategori penilaian aspek afektif siswa, jumlah skor rata-rata dibagi jumlah aspek pengamatan $(20,8: 6=3,46)$, maka kategorinya cukup.

Refleksi dari kolaborator pada tatap muka 2, siklus I dapat dirangkum dan difokuskan pada: mind mapping hendaknya dimaksimalkan, diciptakan interaksi antar siswa, pemberian motivasi agar siswa aktif perlu ditingkatkan, pemberian pujian (reward) perlu ditingkatkan, pengelolaan kelas perlu ditingkatkan, manajemen waktu perlu diperhatikan agar pretes dan post tes dapat dilaksanakan dengan baik.

Tatap muka 3, siklus I, keaktifan siswa sudah mengalami peningkatan dibanding tatap muka sebelumnya, walaupun masih ada beberapa siswa yang masih cenderung diam, mind mapping sudah mulai berfungsi, siswa sesekali saja membuka buku paket apabila di dalam mind mapping belum tertulis. Dalam presentasi banyak siswa yang mau menanggapi hasil diskusi kelompok lain, manajemen waktu masih kurang sehingga belum semua kelompok mempresentasikan hasil diskusinya, namun demikian sudah ada peningkatan dibanding sebelumnya

Refleksi tatap muka 3, siklus I, oleh kolaborator bersama peneliti sebagai berikut: proses pembelajaran dengan min mapping sudah menunjukkan tanda-tanda perbaikan, hal ini dapat dilihat dan beberapa indikator: banyak siswa yang aktif. Pendekatan guru dalam memantau dan mengamati siswa dengan teknik chennel sudah cukup baik, situasi pembelajaran nyaman. Manajemen waktu perlu ditingkatkan, pemberian motivasi juga perlu ditingkatkan, dan siswa yang membuat kesimpulan. Peningkatan proses pembelajaran juga dapat dilihat dari basil analisis penilaian proses pembelajaran, keaktifan siswa juga dapat dilihat dan basil analisis lembar observasi penilaian aspek afektif siswa. sebagai berikut:

\section{Penilaian Proses Pembelajaran}

Berdasarkan penilaian kolaborator terhadap proses pembelajaran mind mapping (menggunakan instrumen I), kolaborator memberikan jumlah skor 78. Untuk menentukan kategori penilaian adalah ratarata jumlah skor dari kolaborator dibagi jumlah butir aspek pengamatan atau $78: 20=$ 3,9, maka penilaian proses pembelajaran kategorinya baik. Distribusi frekuensi skor terdapat pada tabel 3 berikut.

Tabel 3. Rekapitulasi Penilaian Proses Pembelajaran menggunakan Mind Mapping Siklus I, Tatap Muka 3

\begin{tabular}{rlcc}
\hline No. & \multicolumn{1}{c}{ Kategori } & Frekuensi & $\%$ \\
\hline 1 & Sangat Baik & 2 & 10 \\
\hline 2 & Baik & 14 & 70 \\
\hline 3 & Cukup & 4 & 20 \\
\hline 4 & Kurang & 0 & 0 \\
\hline 5 & Sangat Kurang & 0 & 0 \\
\hline & Jumlah & 20 & 100 \\
\hline
\end{tabular}

Berdasarkan tabel 3, hasil penilaian

oleh kolaborator terhadap proses pembelajaran terdapat pada kategori cukup sebesar $20 \%$ dan $70 \%$ baik. 


\section{Penilaian Aspek Afektif Siswa}

Berdasarkan penilaian kolaborator terhadap aspek afektif siswa (instrumen II), diperoleh jumlah skor rata-rata 22,5 (lihat lampiran). Untuk menentukan kategori penilaian aspek afektif siswa, jumlah skor rata-rata dibagi jumlah aspek pengamatan $(22,5: 6=3,75)$, maka kategorinya cukup.

Refleksi dan kolaborator pada tatap muka 3, siklus I dapat kita rangkum dan kita fokuskan pada: mind mapping hendaknya dimaksimalkan, diciptakan interaksi antar siswa, pemberian motivasi agar siswa aktif perlu ditingkatkan, pemberian pujian (reward) perlu ditingkatkan, pengelolaan kelas perlu ditingkatkan, menejemen waktu perlu diperhatikan agar pretes dan post tes dapat dilaksanakan dengan baik.

Ketuntasan belajar siswa dari hasil ulangan aspek kognitif (ulangan harian) pada siklus I, diperoleh nilai terendah 60 , nilai tertinggi 87 , dan nilai rerata 72,53 , sehingga daya serap siswa secara lclasikal 72,53\%. Pencapaian daya serap siswa pada siklus I ini belum tutntas baik secara individual maupun klasikal, sehingga bagi siswa yang belum tuntas diadakan perbaikan (remidial). Bagi siswa yang sudah tuntas dapat membantu belajar siswa yang belum tuntas dengan cara tutor sebaya. Daya serap hasil ulangan harian dapat dilihat pada lampiran.

Berdasarkan hasil refleksi yang dilakukan peneliti dan kolaborator, dapat disimpulkan bahwa ada beberapa permasalahan yang muncul pada saat proses pelaksanaan tindakan siklus I, dan disepakati untuk mengadakan beberapa revisi pada rancangan tindakan siklus I yang sekaligus menjadi rancangan tindakan siklus $\mathrm{H}$. Adapaun tindakan yang direncanakan untuk siklus II masih sama dengan siklus I namun ada beberapa hal yang perlu direvisi meliputi:

1. Dalam memotivasi siswa agar aktif hendaknya lebih ditingkatkan

2. Pengelolaan kelas lebih ditingkatkan

3. Pemberian umpan balik lebih ditingkatkan
4. Manajemen waktu dalam proses pembelajaran perlu diperhatikan.

\section{Siklus II}

Tindakan-tindakan utama pada siklus I tetap dipertahankan, diharapkan tindakan siklus II ini siswa semakin siap dan dapat memahami konsep dengan baik, nyaman dalam belajar, senang belajar ekonomi dan dampak positifnya meningkatkan prestasi belajar ekonomi. Seperti halnya siklus I pelaku tindakan adalah guru ekonomi sebagai peneliti dan dibantu dua orang kolaborator serta foto grafer yang mendokumentasikan kegiatan pembelajaran. Pada siklus ke II ini juga direncanakan dua kali tatap muka.

Keberhasilan tindakan siklus II diindikasikan adanya perubahan-perubahan yang lebih baik (meningkat), pada komponen yang diamati yaitu aspek sikap (kerajinan, perhatian, keaktifan, kerapian ketepatan dan kebenaran). Pada proses pembelajaran peningkatan tersebut akan terlihat jelas terutama pada keaktifan siswa, serta hasil analisis aspek afektif siswa. Sedangkan untuk mengetahui ketuntasan belajar siswa diadakan ulangan harian dan sekaligus dianalisis untuk mengetahi daya serap siswa.

Pada siklus II, tatap muka 1, para siswa sudah semakin siap dengan mind mapping dibanding siklus I, terlihat para siswa sudah menggelar mind mappingnya di atas meja di setiap kelompok. Sebelum diskusi kelompok di mulai guru memberikan pertanyaan sebagai pretest untuk mengetahui sejauh mana kesiapan siswa pada materi yang akan dibahas.

Proses pembelajaran menggunakan mind mapping tatap muka I, siklus II ini, sudah tampak adanya perubahan yang berarti pada komponen-komponen yang diamati seperti sikap siswa dalam kelompok, partisipasi, perilaku, dan interaksi antar siswa. Mind mapping sudah berfungsi, beberapa siswa antusias memahami materi yang ada pada mind mapping, tinggal beberapa siswa yang membuka-buka buku paket, para siswa sudah memanfaatkan mind mapping. 
Disamping catatan lapangan yang berupa diskripsi, juga didukung hasil analisis penilaian proses pembelajaran, dan hasil analisis penilaian aspek afektif siswa. Untuk menentukan kategori penilaian proses pembelajaran dan penilaian aspek afektif siswa yaitu ditentukan persentase pada setiap kategori penilaian. Dari hasil analisis data penilaian proses pembelajaran dan analisis data penilaian aspek afektif siswa dapat diketahui masing-masing kategorinya. Data yang diperoleh dan kedua kolaborator pada proses pembelajaran tatap muka I, siklus II, sebagai berikut:

1. Penilaian Proses Pembelajaran

Berdasarkan penilaian kolaborator terhadap proses pembelajaran dengan mind mapping (menggunakan instrumen I), kolaborator memberikan jumlah skor 84 . Untuk menentukan kategori penilaian adalah jumlah butir aspek pengamatan atau $84: 20=$ 4,2 maka penilaian proses pembelajaran kategorinya baik. Distribusi frekuensi skor dapat dilihat pada tabel 4 berikut.

Tabel 4. Rekapitulasi Penilaian Proses Pembelajaran menggunakan Mind Mapping Siklus II, Tatap Muka 1

\begin{tabular}{|c|c|c|c|}
\hline No. & Kategori & Frekuensi & $\%$ \\
\hline 1 & Sangat Baik & 4 & 20 \\
\hline 2 & Baik & 16 & 80 \\
\hline 3 & Cukup & 0 & 0 \\
\hline 4 & Kurang & 0 & 0 \\
\hline 5 & Sangat Kurang & 0 & 0 \\
\hline & Jumlah & 20 & 100 \\
\hline
\end{tabular}

oleh kolaborator terhadap proses pembelajaran terdapat pada kategori $80 \%$ baik.

\section{Penilaian Aspek Afektif Siswa}

Berdasarkan penilaian kolaborator terhadap aspek afektif siswa (instrumen II), diperoleh jumlah skor rata-rata adalah 24 . Untuk menentukan kategori penilaian aspek afektif siswa jumlah skor rrata-rata dibagi jumlah aspek pengamatan $(24: 6=4)$, maka kategorinya baik
Refleksi dari kolaborator pada tatap muka 1, siklus II dapat kita rangkum dan kita fokuskan pada: mind mapping difungsikan secara maksimal, diciptakan interaksi antar siswa, pemberian motivasi agar siswa aktif perlu ditingkatkan, pengelolaan kelas perlu ditingkatkan, menejemen waktu bar us selalu diperhatikan.

Tatap muka 2, siklus II, keaktifan siswa sudah mengalami peningkatan yang signifikan, mind mapping sudah mulai berfungsi, siswa sesekali saja membuka buku paket dan LKS apabila di dalam mind mapping belum tertulis. Dalam presentasi sudah banyak siswa yang menanggapi hasil diskusi kelompok lain, manajemen waktu sudah bagus sehingga hampir semua kelompok mempresentasikan hasil diskusinya. Hal ini sesuai dengan pengamatan yang dapat dirangkum sebagai berikut: interaksi antar siswa dalam kelompok mind mapping sudah baik, siswa aktif menjawab pertanyaan baik dari guru maupun temannya. Guru mampu membawa proses pembelajaran dalam situasi inti dan menyenangkan. Diskusi sudah bejalan baik, para siswa mulai nyaman belajar dengan mind mapping. Keterlibatan guru dalam setiap kelompok diskusi juga sudah baik, pemberian reward juga sudah baik.

Refleksi tatap muka 2, siklus II, oleh kolaborator bersama peneliti sebagai berikut: proses pembelajaran dengan min mapping sudah baik, hal ini dapat dilihat dari beberapa indikator: banyak siswa yang aktif. Pendekatan guru dalam memantau dan mengamati siswa dengan teknik chennel sudah baik, situasi pembelajaran nyaman dan menyenangkan. Manajemen waktu sudah baik, dan guru hendaknya melibatkan seluruh siswa dalam mengambil kesimpulan. Peningkatan proses pembelajaran juga dapat dilihat dan hasil analisis penilaian proses pembelajaran, keaktifan siswa juga dapat dilihat dan hasil analisis lembar observasi penilaian aspek afektif siswa. Dalam penentuan kategori sebagai berikut: 


\section{Penilaian Proses Pembelajaran}

Berdasarkan penilaian kolaborator terhadap proses pembelajaran mind mapping (menggunakan instrumen 1), kolaborator memberikan jumlah skor 98. Untuk menentukan jumlah butir aspek pengamatan atau $98: 30=3,30$, maka penilaian proses pembelajaran kategorinya cukup. Distribusi frekuensi skor terdapat pada tabel 5 berikut.

Tabel 5. Rekapitulasi Penilaian Proses Pembelajaran menggunakan Mind Mapping Siklus II, Tatap Muka 2

\begin{tabular}{|c|c|c|c|}
\hline No. & Kategori & Frekuensi & $\%$ \\
\hline 1 & Sangat Baik & 8 & 40 \\
\hline 2 & Baik & 12 & 60 \\
\hline 3 & Cukup & 0 & 0 \\
\hline 4 & Kurang & 0 & 0 \\
\hline 5 & Sangat Kurang & 0 & 0 \\
\hline & Jumlah & 20 & 100 \\
\hline
\end{tabular}
pembelajaran terdapat pada kategori baik sebesar $60 \%$ dan $40 \%$ sangat baik.

\section{Penilaian Aspek Afektif Siswa}

Berdasarkan penilaian kolaborator terhdap aspek afektif siswa (instrumen II), diperoleh jumlah skor rata-rata 26,3. Untuk menentukan kategori penilaian aspek afektif siswa, jumlah skor rata-rata aspek pengamatan $(26,3: 6=4,38)$, dengan kategori baik.

Refleksi dan kolaborator pada tatap muka 2, siklus II dapat kita rangkum dan kita fokuskan pada: mind mapping hendaknya difungsikan secara maksimal, diciptakan interaksi antar siswa, pemberian motivasi agar siswa aktif perlu ditingkatkan, pemberian pujian (reward) perlu ditingkatkan, pengelolaan kelas perlu ditingkatkan, menejemen waktu perlu diperhatikan sehingga proses pembelajaran berjalan lancar.

Tatap muka 3, siklus II, keaktifan siswa sudah mengalami peningkatan yang signifikan, mind mapping sudah mulai berfungsi, semua siswa tidak membuka buku paket maupun LKS. Dalam presentasi sudah banyak siswa yang menanggapi hasil diskusi kelompok lain, manajemen waktu sudah bagus sehingga hampir semua kelompok mempresentasikan hasil diskusinya. Hal ini sesuai dengan pengamatan yang dapat dirangkum sebagai berikut: interaksi antar siswa dalam kelompok mind mapping sudah baik, siswa aktif menjawab pertanyaan baik dari guru maupun temannya. Guru mampu membawa proses pembelajaran dalam situasi inti dan menyenangkan. Diskusi sudah bejalan baik, para siswa mulai nyaman belajar dengan mind mapping. Keterlibatan guru dalam setiap kelompok diskusi juga sudah baik, hampir semua siswa yang bisa menjawab pertanyaan dengan benar mendapat reward dari guru.

Refleksi tatap muka 3, siklus II, oleh kolaborator bersama peneliti sebagai berikut: proses pembelajaran dengan mind mapping sudah baik, hal ini dapat dilihat dari beberapa indikator: banyak siswa yang aktif. Pendekatan guru dalam memantau dan mengamati siswa sudah baik, situasi pembelajaran nyaman dan menyenangkan. Manajemen waktu sudah baik, guru sudah mengarahkan seluruh siswa dalam mengambil kesimpulan. Peningkatan proses pembelajaran dapat dilihat dari hasil analisis penilaian proses pembelajaran.

Dalam penentuan kategori sebagai berikut:

1. Penilaian Proses Pembelajaran

Berdasarkan penilaian kolaborator terhadap proses pembelajaran mind mapping (menggunakan instrumen I), kolaborator memberikan jumlah skor 90. Untuk menentukan kategori penilaian adalah jumlah butir aspek pengamatan atau 90:20 $=4,5$, masuk dalam kategori baik.

Tabel 6. Rekapitulasi Penilaian Proses Pembelajaran menggunakan Mind Mapping Siklus H, Tatap Muka 3

\begin{tabular}{clcc}
\hline No. & Kategori & Frekuensi & $\%$ \\
\hline 1 & Sangat Baik & 10 & 50 \\
\hline 2 & Baik & 10 & 50 \\
\hline 3 & Cukup & 0 & 0 \\
\hline 4 & Kurang & 0 & 0 \\
\hline 5 & Sangat Kurang & 0 & 0 \\
\hline & Jumlah & 20 & 100 \\
\hline
\end{tabular}


Berdasarkan tabel 6, basil penilaian oleh kolaborator terhadap proses pembelajaran terdapat pada kategori baik sebesar $50 \%$ dan $50 \%$ sangat baik.

\section{Penilaian Aspek Afektif Siswa}

Berdasarkan penilaian kolaborator terhadap aspek afektif siswa (instrumen II), diperoleh jumlah skor rata-rata 27,85. Untuk menentukan kategori penilaian aspek afektif siswa, jumlah skor rata-rata aspek pengamatan $(27,85: 6=4,64)$, maka kategorinya baik.

Untuk mengetahui penilaian aspek kognitf, diakhir siklus diadakan ulangan harian, kemudian hasilnya dianalisis untuk mengetahui daya serap siswa baik secara individual maupun klasikal dan untuk mengetahui ketuntasan belajar siswa. Nilai terendah 73 dan nilai tertinggi 100, nilai ratarata 82,6 dan daya serap hasil ulangan harian siklus ke II ini sudah mencapai ketuntasan yaitu $82,6 \%$.

\section{PEMBAHASAN}

Ketuntasan belajar ekonomi di kelas X IPA sulit dicapai sehingga berdampak prestasi belajar ekonomi juga sulit diwujudkan, untuk itu peneliti melakukan penelitian tindakan tentang Upaya peningkatan prestasi belajar ekonomi siswa menggunakan mind mapping di kelas tersebut.

Hasil yang dicapai pada setiap tatap muka dalam setiap siklus menunjukan perubahan keaktifan siswa yang signifikan, begitu juga interaksi antar siswa dan interaksi guru-siswa. Siswa merasa termotivasi dan senang belajar ekonomi karena merasa dilibatkan, ada keleluasaan dalam berekspresi, mengemukakan pendapat, bertanya dan menanggapi pertanyaan temannya sehingga merasa senang dan nyaman. Manfaat yang lain dapat menjalin kerja sama antar teman, tidak egois, dengan mind mapping dapat belajar berulang kali sehingga mudah memahami konsep yang sedang dipelajari.
Proses pembelajaran dari siklus I sampai siklus II mengalami peningkatan yang signifikan, hal ini dapat dilihat dari rekapitulasi penilaian pembelajaran oleh kolaborator pada tabel berikut.

Tabel 7. Rekapitulasi Kategori Penilaian Proses Pembelajaran Menggunakan Mind Mapping Selama Dua Siklus

\begin{tabular}{ccccc}
\hline \multirow{2}{*}{ Siklus } & & \multicolumn{3}{c}{ Kategori (\%) } \\
\cline { 2 - 5 } & & Tatap & Baik & Sangat \\
\hline \multirow{3}{*}{ I } & 1 & 75 & 25 & 0 \\
\cline { 2 - 5 } & 2 & 50 & 50 & 0 \\
\cline { 2 - 5 } & 3 & 20 & 70 & 10 \\
\hline \multirow{3}{*}{ II } & 1 & 0 & 80 & 20 \\
\cline { 2 - 5 } & 2 & 0 & 60 & 40 \\
\cline { 2 - 5 } & 3 & 0 & 50 & 50 \\
\hline
\end{tabular}

Dari tabel $7 \mathrm{di}$ atas, dapat diketahui bahwa dari siklus I sampai siklus II, terjadi peningkatan proses pembelajaran dari cukup menjadi baik, kemudian menjadi sangat baik. Hasil rekapitulasi daya serap siswa juga menjadi data pendukung prestasi belajar ekonomi siswa selama dua siklus dan dapat dilihat pada tabel 8 berikut.

Tabel 8. Rekapitulasi Ketuntasan Belajar Siswa Selama Dua siklus

\begin{tabular}{|c|c|c|}
\hline Siklus & Persentase $(\%)$ & Keterangan \\
\hline $\mathrm{I}$ & 72,53 & Belum Tuntas \\
\hline II & 82,63 & Tuntas \\
\hline
\end{tabular}
peningkatan ketuntasan belajar siswa aspek kognitif dan silkus I sampai siklus II, hal ini merupakan data pendukung keberhasilan tindakan Upaya Peningkatan Prestasi Belajar Ekonomi Siswa menggunakan Mind Mapping.

\section{KESIMPULAN}

Berdasarkan hasil pembahasan pada penelitian tindakan kelas, didukung hasil analisis data penilaian proses pembelajaran, penilian aspek afektif siswa, hasil belajar siswa aspek kognitif (ketuntasan siswa) dan hasil wawancara, maka kesimpulannya adalah Mind 
mapping, meningkatkan prestasi belajar ekonomi pada siswa kelas X IPA SMA Negeri 1 Galur Kulon Progo. Peningkatan tersebut terjadi pada: 1) interaksi guru siswa. 2) interaksi antar siswa. 3) aspek afektif siswa. 4) aspek kognitif (ketuntasan siswa).

Berdasarkan kesimpulan di atas maka dikemukakan sara-saran sebagai berikut: dalam pembelajaran ekonomi guru dianjurkan kreatif, inovatif, menggunakan media dan metode yang berbeda dari biasanya, agar proses pembelajaran ekonomi menjadi menarik, menyenangkan dan bermakna.

\section{DAFTAR PUSTAKA}

Alamsyah, Maurizal. (2009). Kiat Jitu Meningkatkan Prestasi dengan Mind Mapping. Yogyakarta: Mitra Pelajar.

Block, J. H. (1971). Mastery learning. New York: Holt, Rinerhart and Wiston, Inc.

Burns, A. (1999). Collaborative action research for english language teachers. Cambridge University Press.

Buzan, T. (2008). Buku Pintar Mind Map. Jakarta: PT Gramedia Pustaka Utama.

Jensen, Eric \& Karen, Majowitz. (2002). Otak Sejuta Gygabite: Buku Pintar membangun Ingatan Super. Bandung: Kaifa.

Rudianto, A. (2016) Buku Siswa Ekonomi SMA / MA Kelas X Edisi Revisi. Jakarta: Erlangga. 